\title{
A SPREADSHEET TO SUPPORT THE SUZUKI ABCD METHOD
}

\author{
Bartosz SZCZEŚSNIAK \\ Silesian University of Technology, Faculty of Organization and Management, Zabrze; \\ Bartosz.Szczesniak@polsl.pl, ORCID: 0000-0002-9683-4629
}

Purpose: Main aims of research is to create and present the concept of using a spreadsheet to create a tool supporting the assessment of significance of causes in accordance with the principles of the Suzuki ABCD method.

Design/methodology/approach: The ABCD method itself was discussed first. Based on the literature research, several different variants have been identified. One chosen option has been described in more detail. A support tool has been proposed for this option. Its structure was discussed. The two main elements of the tool are presented in detail, including the workbook, in which the assessment is performed, and the aggregate workbook. Solutions used to support individual significance assessments and solutions for the automatic generation of required summaries were presented and discussed.

Findings: The presented solution shows that the spreadsheet can be treated as a sufficient environment to create a tool supporting the Suzuki ABCD analysis. The assumed functionality of the tool can be obtained without the need to register macros or create code in any programming language.

Practical implications: The presented solution can be used when applying the Suzuki ABCD method in practice.

Originality/value: The described concept is an original solution created by the author.

Keywords: assessment of significance of causes, improvement of information processes, quality management, spreadsheet

Category of the paper: Conceptual and technical paper

\section{Introduction}

At present, it is difficult to imagine the functioning of any organisation without using more or less complex IT tools supporting various areas of its activity. The solutions used include both extensive and very advanced systems integrating many different functional areas, as well as much smaller and simpler tools developed to support specific processes, methods and analyses. The tools used can be both bought on the market and manufactured independently within the organisation. Spreadsheets are a very convenient platform for creating your own IT solutions. 
They are known and widely used in almost every company. Many literature positions widely discuss their structure and how to use individual mechanisms or functions. In many literature positions, you can also find a proposal to use this group of tools to solve specific problems in the enterprise. The concepts of using spreadsheets in the areas of controlling, accounting and financial analysis are proposed (Carlberg, 2009; Jackson, and Staunton, 2004; Niezgodziński, 2000; Szczęśniak, and Wolniak, 2016; Winston, 2011), in the areas of marketing and sales (Carlberg, 2009; Wilczewski, and Wrzód 2008; Flanczewski, 2010), in the scope of work time scheduling (Szczęśniak, 2010a; Zasadzień et al., 2017) and in the field of quality management (Knight, 2006; Szczęśniak, 2010b; Szczęśniak, and Molenda, 2013). The last of the mentioned areas includes the ABCD method, for which the concept of support using a tool created in a spreadsheet is discussed later in this article.

\section{The ABCD method}

The ABCD method, also known as the Suzuki method, is a relatively simple method that allows for determining the significance of specific causes of a particular problem. A condition for its successful application is to have a team of experts who know the analysed issue well enough. Carrying out the entire analysis assumes the implementation of a number of steps. First, it is necessary to precisely identify the causes that will be subject to the significance assessment. In the second step, each member of the expert team must individually assess the significance of individual causes on a properly prepared evaluation form. After the assessment, based on all individual results, an aggregate summary is created, based on which the rank indicator determining its significance is calculated for each of the causes. In the last step, a summary is prepared, in which all the causes are arranged, based on the significance determined for them.

There are various concepts in the literature regarding the way in which the assessment of the significance of causes should be expressed. Both Łańcucki (Łańcucki, 2003) and Łuczak (Luczak, 2007) propose to use for this purpose a scale from 1 to 10 , where the value of 1 means the most important cause and the value of 10 means the least significant cause. Normally, during the assessment, each person must assign to each of the causes an assessment determining its significance. These authors also mention another practicable approach, according to which each person chooses the 10 most significant causes and assigns them numbers from 1 to 10 . In this approach, in individual assessment, each number can only be assigned once to one selected cause. Miller (Miller, 2011) also proposes a 10 degree scale, in which case the most significant cause is assigned the value 10 and the least significant cause is 1 . A 10 degree scale is proposed here, as the most commonly used scale. Therefore, it is also permissible to use a different scale. The 6 degree scale is used in the Cholewa-Wójcik study (Cholewa-Wójcik, 
2014). A grade of 5 is assigned here for the most, and a grade of 0 for the least important. As you can see, it is possible to identify several variants of the ABCD method that differ from each other:

- range of the scale used ( $\mathrm{A}$ - scale from 1 to $10, \mathrm{~B}$ - other scale),

- determination of the highest and lowest significance (1 - the lowest value means the highest significance, 2 the lowest value means the least significant),

- assigning grades to all or only selected causes (a - grades assigned to all causes, $\mathrm{b}$ - grades assigned to selected arranged causes).

A proposal for various variants of the ABCD method is presented in Table 1 .

Table 1.

Variants of the ABCD method

\begin{tabular}{|c|c|c|c|c|c|}
\hline & & \multicolumn{4}{|c|}{ Range of the scale } \\
\hline & & \multicolumn{2}{|c|}{$\mathbf{A}$} & \multicolumn{2}{|c|}{ B } \\
\hline & & \multicolumn{4}{|c|}{ Determination of significance } \\
\hline & & 1 & 2 & 1 & 2 \\
\hline \multirow{2}{*}{ Assigning grades } & $\mathbf{a}$ & A1a & A2a & B1a & $\mathrm{B} 2 \mathrm{a}$ \\
\hline & $\mathbf{b}$ & A1b & $\mathrm{A} 2 \mathrm{~b}$ & B1b & $\mathrm{B} 2 \mathrm{~b}$ \\
\hline
\end{tabular}

The rest of the article focuses on Variant A1a. This option uses a 10 point grade scale, each team member must assign a grade to each cause, and the highest significance is expressed by grade 1 . Individual assessment of the reasons is carried out using forms, the layout of which may be consistent with the layout presented in Table 2 .

Table 2.

An example form for individual assessment of the significance of causes

\begin{tabular}{|l|l|l|l|l|l|l|l|l|l|l|l|l|}
\hline \multicolumn{1}{|l|}{ Cause } & \multicolumn{10}{|c|}{ The rank (meaning) of the cause } & \multirow{2}{*}{ Comments } \\
\hline Series & Name & $\mathbf{1}$ & $\mathbf{2}$ & $\mathbf{3}$ & $\mathbf{4}$ & $\mathbf{5}$ & $\mathbf{6}$ & $\mathbf{7}$ & $\mathbf{8}$ & $\mathbf{9}$ & $\mathbf{1 0}$ & \\
\hline & & & & & & & & & & & & \\
\hline & & & & & & & & & & & & \\
\hline
\end{tabular}

Source: Łańcucki, J. (2003). Podstawy kompleksowego zarządzania jakością TQM.

The assessment of the significance of a given cause is made by placing a specific symbol in the cell at the intersection of the row, in which the given cause is located, and the column in which the assessment is located. After individual assessments, an aggregate summary of results is created. The layout of the summary may be consistent with the layout presented in Table 3. 
Table 3.

Sample aggregate summary of results

\begin{tabular}{|c|c|c|c|c|c|c|c|c|c|c|c|c|c|c|c|}
\hline \multicolumn{2}{|c|}{ Cause } & \multicolumn{10}{|c|}{ The rank (meaning) of the cause } & \multirow{2}{*}{ 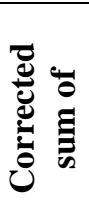 } & \multirow{2}{*}{ 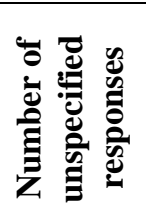 } & \multirow[b]{2}{*}{ 兰泀 } & \multirow[b]{2}{*}{ 華 } \\
\hline$\stackrel{\mathscr{E}}{\mathscr{E}}$ & 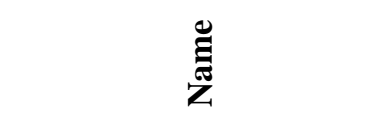 & 1 & 2 & 3 & 4 & 5 & 6 & 7 & 8 & 9 & 10 & & & & \\
\hline A & no crew training & & 2 & 4 & 3 & 1 & & & & & & 26 & 8 & 3.25 & 2 \\
\hline B & $\begin{array}{l}\text { poor organisation of work } \\
\text { when implementing the } \\
\text { system }\end{array}$ & 1 & 4 & 3 & 2 & & & & & & & 21 & 8 & 2.625 & 1 \\
\hline $\mathrm{C}$ & $\begin{array}{l}\text { too complex system of } \\
\text { documentation }\end{array}$ & & & 1 & 2 & 3 & 3 & 1 & & & & 41 & 8 & 5.125 & 3 \\
\hline
\end{tabular}

Source: Łańcucki, J. (2003). Podstawy kompleksowego zarządzania jakością TQM.

In this table, first of all, for each cause, it is determined how many times the individual numbers indicating the rank of the cause appeared in individual assessments. For example, the number 4 in the cell, at the intersection of the column with the score 2 and the row with the cause B, means that - among all assessors - the grade 2 for the cause B occurred 4 times. In the next step, the corrected sum of meanings is calculated for each cause. It is calculated as the sum of the products of individual grades and the number of their occurrences, with two extreme grades omitted. An example of the corrected sum of meanings for cause B is: $2 \times 4+3 \times 3+4 \times 1=21$. One grade of 1 and one grade of 4 are omitted from the calculation. The rank indicator is calculated based on the corrected sum of meanings. This indicator is the quotient of the corrected sum of meanings by the number of unspecified responses. On its basis, the final significance of each of the causes is determined. The lower the rank indicator, the more important the given cause. In the last step, all causes are arranged based on the significance determined, so as to obtain a summary in accordance with Table 4.

Table 4.

Sample arranged aggregate summary of results

\begin{tabular}{|c|c|c|c|c|c|c|c|c|c|c|c|c|c|c|c|}
\hline \multicolumn{2}{|c|}{ Cause } & \multicolumn{10}{|c|}{ The rank (meaning) of the cause } & \multirow{2}{*}{ 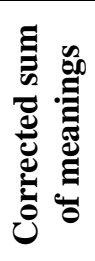 } & \multirow{2}{*}{ 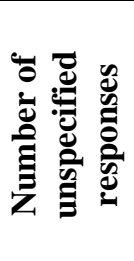 } & \multirow{2}{*}{ 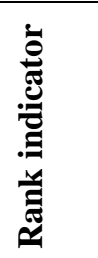 } & \multirow[b]{2}{*}{ 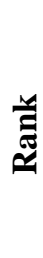 } \\
\hline$\cdot \stackrel{\mathscr{2}}{\mathscr{0}}$ & 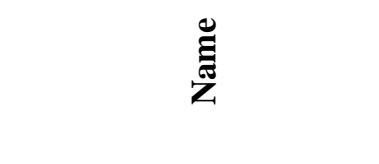 & 1 & 2 & 3 & 4 & 5 & 6 & 7 & 8 & 9 & 10 & & & & \\
\hline $\mathrm{B}$ & $\begin{array}{l}\text { poor organisation of work } \\
\text { when implementing the } \\
\text { system }\end{array}$ & 1 & 4 & 3 & 2 & & & & & & & 21 & 8 & 2.625 & 1 \\
\hline $\mathrm{A}$ & no crew training & & 2 & 4 & 3 & 1 & & & & & & 26 & 8 & 3.25 & 2 \\
\hline $\mathrm{C}$ & $\begin{array}{l}\text { too complex system of } \\
\text { documentation }\end{array}$ & & & 1 & 2 & 3 & 3 & 1 & & & & 41 & 8 & 5.125 & 3 \\
\hline
\end{tabular}

Source: own study based on Łańcucki, J. (2003). Podstawy kompleksowego zarządzania jakością TQM. 
The ABCD method is mainly presented as a method to arrange the causes. This approach can also be used in other areas, such as determining the significance of customer requirements (Knop, 2016) and their needs (Cholewa-Wójcik, 2014). Nothing stands in the way of it assessing the significance of product features and purposes. Due to the universality of the method later in the study, in relation to the subject of assessment of the significance, the concept element will be used instead of the concept cause.

\section{Construction of the tool}

The tool created to support the ABCD method consists of two spreadsheet workbooks. The first of these is a form filled in by persons participating in the assessment of the significance of individual elements. Each of the assessors makes an assessment in their file. The second is a summary file, in which all data is collected and in which the results of the analysis are generated. It was assumed, that the tool can include a maximum of 30 elements, the significance of which can be assessed by a maximum of 100 people.

\subsection{Workbook - form}

The workbook that acts as a form contains one worksheet named "FORM". The layout of cells in this worksheet is as shown in Figure 1.

\begin{tabular}{|c|c|c|c|c|c|c|c|c|c|c|c|c|}
\hline$\angle$ & A & B & C & D & $E$ & $\mathrm{~F}$ & G & $\mathrm{H}$ & 1 & J & K & $\mathrm{L}$ \\
\hline 1 & & & \multicolumn{10}{|c|}{ Rank } \\
\hline 2 & Person & Element & 1 & 2 & 3 & 4 & 5 & 6 & 7 & 8 & 9 & 10 \\
\hline 3 & Aaa Bbb & EL_1 & & & $x$ & & & & & & & \\
\hline 4 & Aaa Bbb & El_2 & & & & $x$ & & & & & & \\
\hline 5 & Aaa Bbb & EL_3 & & & & & & $x$ & & & & \\
\hline 6 & Aaa Bbb & EL_4 & & & & & & $x$ & & & & \\
\hline 7 & Aaa Bbb & El_5 & & $x$ & & & & & & & & \\
\hline 8 & Aaa Bbb & EL_6 & $x$ & & & & & & & & & \\
\hline 31 & Aaa Bbb & EL_29 & & & & & & & & & & $x$ \\
\hline 32 & Aaa Bbb & EL_30 & & & & & & & $x$ & & & \\
\hline
\end{tabular}

Figure 1. The layout of cells in the FORM worksheet.

There are defined names of graded elements in this worksheet in range B3:B32, and the assessor should enter their name in cell A3, after which they should assess individual elements by entering " $x$ " in the appropriate cell of range C3:L32.

This form uses solutions that verify the correctness of its completion. As part of these solutions, auxiliary columns have been added. Their arrangement with the formulas used is presented in Figure 2. 


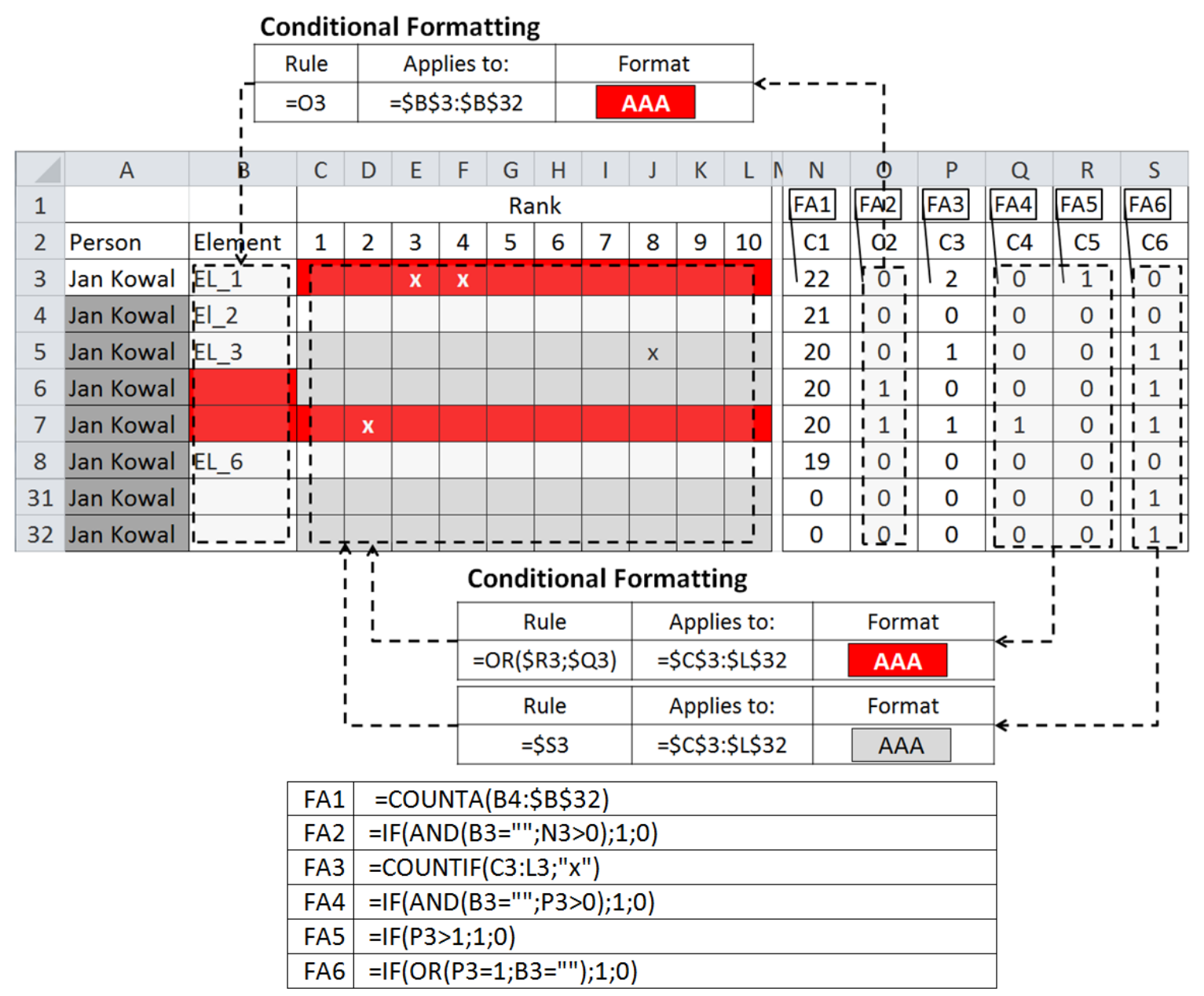

Figure 2. Auxiliary column and formula solutions that verify the correctness of completing the form.

The auxiliary columns $\mathrm{C} 1$ and $\mathrm{C} 2$ contain formulas that verify, whether in the B3:B32 range, the names of the elements taken into account in the analysis were entered without leaving any gaps. The FA1 formula checks how many element names appear in subsequent rows of the assumed range. If there are any names in these rows and, at the same time, no name has been entered in the current row, the FA2 function returns a value of 1, indicating that there is a gap in the given row. Cells that create a gap are filled in red using conditional formatting.

Columns C3, C4, C5 contain formulas that verify the correct number of " $\mathrm{x}$ " values for individual elements. In the event that the element name is not entered in a given row, no value " $x$ " should be entered in it. If such a value appears, it is identified by the formula FA4, which, in this case, returns the value of 1 in column C4. Regardless of the element name entered, no more than one " $x$ " value may be present per row. In the event of such a situation, this is identified by returning 1 by the FA5 formula. Based on the values from the C4 and C5 auxiliary columns, rows containing incorrectly entered " $x$ " values are highlighted in red using conditional formatting.

In addition, to facilitate the completion of the form, the formula FA6 in column C6, returning the value 1 , identifies the rows in which the value " $x$ " should not be entered. This is the case when no element name is entered in these rows or the value " $x$ " has already 
been entered in them. These rows are filled in grey using conditional formatting. Rows, in which subsequent " $x$ " values can be entered, remain filled in white.

The "FORM" worksheet also uses conditional formatting to highlight the red A3 cell in a situation where the surname and first name of the assessor are not entered. Additionally, using the data validation mechanism, the values possible to enter in the C3:L32 range were limited so that only the value " $x$ " was entered in it.

\subsection{Aggregate Workbook}

Data from forms is collected and analysed in an aggregate workbook. There are three worksheets in it: FORM_ALL, RESULTS and RESULTS_O. Grades obtained from persons participating in the analysis are copied to the FORM_ALL worksheet. Based on them, the rankings for individual elements are determined in the RESULTS worksheet, and the final summary is generated on their basis. The general diagram of the worksheets and the links between them are presented in Figure 3.

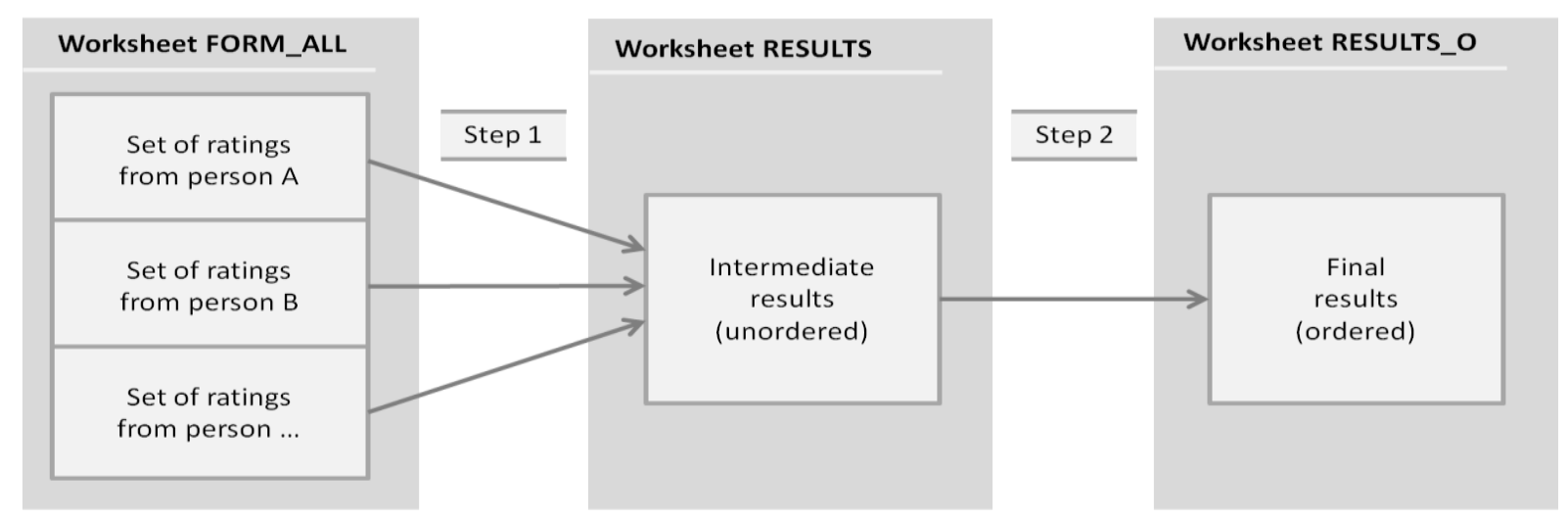

Figure 3. Links between worksheets in an aggregate workbook.

In step 1 , it is necessary to determine the number of individual responses for each of the analysed elements and to determine the arrangement index based on them. To this end, auxiliary cells have been added to both the FORM_ALL worksheet and the RESULTS worksheet. The auxiliary table T1 used in the FORM_ALL worksheet is presented in Figure 4.

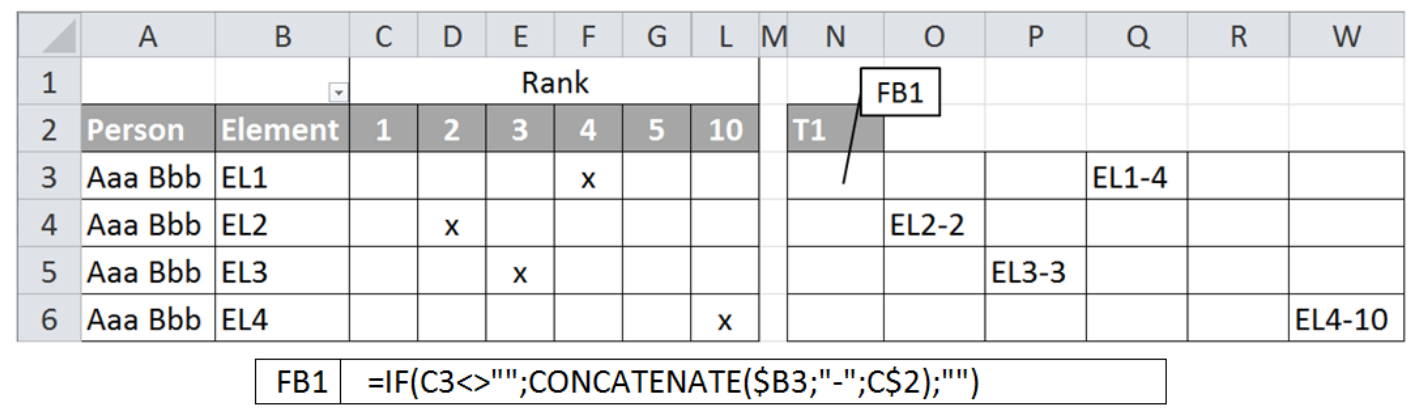

Figure 4. Auxiliary table in worksheet FORM_ALL. 
Each cell in this table is linked to the corresponding cell in range $\mathrm{C} 3: \mathrm{C} 3002$. If, in this range, in one of the cells there is a grading symbol, in the auxiliary table, a code containing the name of the element and the assigned grade is generated in the corresponding cell. This code is used by the formula found in the RESULTS worksheet. The cells of this worksheet of summary results, assumed in the ABCD method, as well as the columns and auxiliary table added together with the formulas used in them, are presented in Figure 5.

\begin{tabular}{|c|c|c|c|c|c|c|c|c|c|c|c|c|c|c|c|c|c|c|c|c|}
\hline$\angle$ & A & B & C & D & $E$ & $F$ & K & L M & $\mathrm{N}$ & 0 & $P$ & Q & V V & $x$ & & $\bar{Z} A$ & & $A B$ & $A C$ & $A D$ \\
\hline 1 & & $\mathrm{~F}$ & $\mathrm{C} 1$ & & & & & & $\mathrm{FC} 2$ & & & & $\mathrm{FC} 3$ & & & $=\mathrm{C} 5$ & $\mathrm{FCE}$ & & $\mathrm{C7}$ & \\
\hline 2 & Eler & 1 & 2 & 3 & 4 & 5 & 10 & T2 & & & & & & C7 & |c8 & & S & NR & RI & $\mathbf{R}$ \\
\hline 3 & EL1 & 1 & 4 & & 2 & 1 & & 1 & 2 & & 4 & 5 & & 1 & 5 & & 6 & 6 & 2,67 & 5 \\
\hline 4 & EL2 & 5 & 1 & 1 & 1 & & & 1 & 2 & 3 & 4 & & & 1 & 4 & & 9 & 6 & 1,50 & 2 \\
\hline 5 & EL3 & 1 & 4 & 3 & & & & 1 & 2 & 3 & & & & 1 & 3 & & 4 & 6 & 2,33 & 4 \\
\hline 6 & EL4 & & & 5 & & & 1 & & & 3 & & & 10 & 3 & 10 & & 5 & 6 & 4,17 & 10 \\
\hline
\end{tabular}

\begin{tabular}{|c|c|}
\hline FC1 & $\begin{array}{l}=I F\left(C O U N T I F\left(F O R M \_A L L ! \$ N \$ 3: \$ W \$ 3002 ; C O N C A T E N A T E(\$ A 3 ; "-" ; B \$ 2)\right)>0 ;\right. \\
\text { COUNTIF(FORM_ALL!\$N\$3:\$W\$3002;CONCATENATE(\$A3;"-";B\$2));"') }\end{array}$ \\
\hline $\mathrm{FC2}$ & $=\mid \mathrm{IF}\left(\mathrm{B} 3<>"{ }^{\prime} " ; \mathrm{B} \$ 2 ; "\right.$ "') \\
\hline FC3 & =IF(A3<>"'";MIN(M3:V3);"'") \\
\hline FC4 & $=$ IF(A3<>"'";MAX(M3:V3);"'") \\
\hline FC5 & =IF(A3<>"'";SUMPRODUCT(\$B\$2:\$K\$2;B3:K3)-X3-Y3;"'") \\
\hline FC6 & $=\operatorname{lF}\left(\mathrm{A} 3<>"{ }^{\prime \prime} ; \mathrm{SUM}(\mathrm{B} 3: \mathrm{K} 3)-2 ; "\right.$ "') \\
\hline FC7 & $=I F(A 3<>" ' ; A A 3 / A B 3 ; " ")$ \\
\hline FC8 & 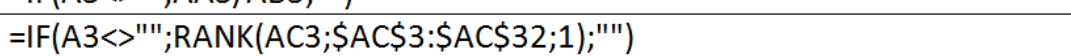 \\
\hline
\end{tabular}

Figure 5. The layout of cells and formulas used during step 1 in the RESULTS worksheet.

Based on the code generated in Table T1, located in range B3:K32, the FC1 formula determines the number of individual grades assigned to each element. In the T2 auxiliary table, each row creates an aggregate of grades that have been assigned to the current element at least once. On its basis, the maximum grade and the minimum grade are identified in auxiliary columns C7 and C8. Based on these quantities, the corrected sum of meanings, corrected number of responses, rank indicator and rank are determined in columns CS, NR, RI and R. The summary prepared in this way includes all quantities assumed in the ABCD method.

In step 2, it is necessary to arrange the elements based on the determined rank values. To implement this step, a solution proposed in the literature for automatic data sorting was used (Szczęśniak, 2007; Szczęśniak 2010b). Auxiliary columns have been added in both the RESULTS worksheet and the RESULTS_O worksheet. The columns used in the RESULTS worksheet are shown in Figure 6. 


\begin{tabular}{|c|c|c|c|c|c|c|c|c|c|c|c|c|c|c|c|c|c|}
\hline 4 & A & B & $C$ & D & $E$ & $\mathrm{~F}$ & G & $\mathrm{H}$ & 1 & J & \multicolumn{2}{|c|}{$K \perp A A$} & $A B$ & $A C$ & \multicolumn{2}{|c|}{$A D \& A F$} & AG \\
\hline 1 & & \multicolumn{10}{|c|}{ Rank } & & & & FD1 & \multicolumn{2}{|c|}{ FD2 } \\
\hline 2 & Eler & 1 & 2 & 3 & 4 & 5 & 6 & 7 & 8 & 9 & 10 & $\mathrm{CS}$ & NR & RI & $\mathbf{R}$ & $\mathrm{CP}$ & C10 \\
\hline 3 & EL1 & 1 & 4 & & 2 & 1 & & & & & & 16 & 6 & 2,67 & 5 & 1 & 5 \\
\hline 4 & EL2 & 5 & 1 & 1 & 1 & & & & & & & 9 & 6 & 1,50 & 2 & 1 & 2 \\
\hline 5 & EL3 & 1 & 4 & 3 & & & & & & & & 14 & 6 & 2,33 & 4 & 1 & 4 \\
\hline 6 & EL4 & & & 5 & & & 1 & 1 & & & 1 & 25 & 6 & 4,17 & 10 & 1 & 10 \\
\hline FD1 & & $=|r|$ & & 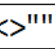 &,$c$ & U & IVI & 18 & AD & & & & & & & & \\
\hline FD2 & & $=\mathrm{IF}(\mathrm{H}$ & $A 3<$ & $<>"$ & ";AL & $D^{3}$ & $+\mathrm{AF}$ & $3-1$ & ;"") & & & & & & & & \\
\hline
\end{tabular}

Figure 6. Auxiliary columns and formulas used during step 2 in the RESULTS worksheet.

The basis for arranging all assessed items is the determined rank value in the R column. In order to move individual elements to specific rows of an arranged structure, a number should be generated next to each of them, indicating the number of the arranged structure row, to which the given element should be moved. The rank could be treated as such a number, were it not for the fact that its values can be repeated for several different assessed elements. In relation to the above, it is necessary to determine the corrected rank, calculated in a way that guarantees its uniqueness for each of the elements. For this purpose, in column C9, the formula FD1 returns a number specifying the number of times the current rank value appears in column $\mathrm{R}$ in the range of rows from 3 to the current. Using the value from the C9 column, the FD2 formula returns the corrected rank value in the $\mathrm{C} 10$ column. The layout of cells and formulas in the RESULTS_O worksheet is presented in Figure 7.

\begin{tabular}{|c|c|c|c|c|c|c|c|c|c|c|c|c|c|c|c|c|}
\hline 4 & A & B & C & D & $\mathrm{E}$ & $\mathrm{F}$ & G & $\mathrm{H}$ & 1 & $\mathrm{~J}$ & \multirow{2}{*}{\multicolumn{2}{|c|}{ LM }} & $\mathrm{N}$ & 0 & \multicolumn{2}{|c|}{$\mathrm{P} Q \mathrm{R}$} \\
\hline 1 & FE2 & \multicolumn{9}{|c|}{ Rank } & & & & & \begin{tabular}{|l|} 
FE1 \\
\end{tabular} & \\
\hline 2 & Element & 1 & 2 & 3 & \begin{tabular}{l|l}
4 \\
\end{tabular} & 5 & 6 & 7 & 8 & \begin{tabular}{l|l}
9 & 1 \\
\end{tabular} & 10 & \begin{tabular}{|l|l} 
CS & 1 \\
\end{tabular} & NR & $\mathrm{RI}$ & $R$ & C11 \\
\hline 3 & EL12 & 6 & 1 & 1 & & & & & & & & 7 & 6 & 1,17 & 1 & 12 \\
\hline 4 & EL2 & 5 & 1 & 1 & 1 & & & & & & & 9 & 6 & 1,50 & 2 & 2 \\
\hline 5 & EL13 & & 7 & & 1 & & & & & & & 12 & 6 & 2,00 & 3 & 13 \\
\hline 6 & EL3 & 1 & 4 & 3 & & & & & & & & 14 & 6 & 2,33 & 4 & 3 \\
\hline FE1 & $=$ IFERF & & IIVIr & . & $\pi$ & 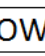 & ( & (2) & 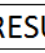 & ULTS & $S ! \$ A$ & G\$3 & $3: \$ A C$ & G\$32; & 0);"') & \\
\hline FE2 & $=I F(\$ R$ & $3<>$ & >"'"। & ND & $\mathrm{EX}(\mathrm{R}$ & $\mathrm{ESL}$ & ULT & $S ! A$ & $\$ 3$ & :A\$3 & $32 ; R$ & ESUI & LTS__ & $\mathrm{O} \$ \mathrm{R}$ & $3 ; 1) ; "$ & \\
\hline
\end{tabular}

Figure 7. Cells and formulas in the RESULTS_O worksheet.

In this worksheet, the first thing to determine in column $\mathrm{C} 11$ is the row number, in which the RESULTS worksheet has the element that should appear in the current arranged row. On this basis, the FE2 formula retrieves the appropriate name of the assessed element from the RESULTS worksheet. Remaining values are retrieved using analogous formulas. In this way, the final summary of elements is generated along with all the values calculated in the ABCD method. 


\section{Conclusions}

The presented solution shows that the spreadsheet can be treated as a sufficient environment to create a tool supporting the Suzuki ABCD analysis. The described tool has been divided into two parts. The first one supports the process of individual assessment of the significance of individual elements. The second one allows easy collection of all obtained responses and automatic generating of reports assumed in the $\mathrm{ABCD}$ analysis. When carrying out the analysis, it is necessary to select one person to coordinate its course. After identifying the elements to be assessed, the person must prepare a workbook containing the FORM worksheet and place it in a space accessible to all other people. Each assessor downloads a prepared workbook, carries out the assessment of significance, and then saves the file under its unique name. After all assessors have completed the assessment, the coordinator copies the results to the FORM_ALL worksheet of the aggregate workbook. Based on copied results, both summaries assumed in the analysis are automatically generated.

A relatively small range of built-in functions and elements of the spreadsheet were used to create the presented data-automating tool. This includes elements, such as conditional formatting and data validation, as well as functions, such as: $\operatorname{COUNTA}(), \operatorname{IF}(), \operatorname{AND}()$, COUNTIF(), OR(), CONCATENATE(), SUMPRODUCT(), MIN(), MAX(), SUM(), RANK(), IFERROR(), MATCH(), INDEX(), ROW(). The assumed functionality of the tool was obtained without the need to register macros or create code in any programming language. Adding this element would improve the proposed solution. One area that could be improved by using VBA code is the process of transferring results from individual workbooks to an aggregate workbook.

\section{Acknowledgements}

This paper was financed from the resources of the Silesian University of Technology, project no. BK-235/ROZ-1/2020 (13/010/BK_20/0042). 


\section{References}

1. Carlberg, C. (2009). Microsoft Excel 2007 PL. Analizy biznesowe. Rozwiazania w biznesie. Gliwice: Helion.

2. Cholewa-Wójcik, A. (2014). Usefulness verification of the ABCD-Suzuki method in order to analyse the consumer's needs and requirements concerning cosmetics product packaging. In: J.J. Lewandowski, A. Walaszczyk, and I. Jałmużna (Eds.), Product and Packaging. Contemporary Challenges (pp. 35-48). Łódź: Wydawnictwo Politechniki Łódzkiej.

3. Flanczewski, S. (2010). Excel w biurze i nie tylko. Gliwice: Helion.

4. Jackson, M., and Staunton, M. (2004). Zaawansowane modele finansowe z wykorzystaniem Excela $i$ VBA. Gliwice: Helion.

5. Knight, G. (2006). Excel. Analiza danych biznesowych. Gliwice: Helion.

6. Knop, K. (2016). Using a QFD method and CTQ tree to identify the areas needing improvement in the product - farm truck trailer. Zeszyty Naukowe Politechniki Ślaskiej. Organizacja i Zarzadzanie, 87, pp. 220-236. Retrieved from: http://www.woiz.polsl.pl/ znwoiz/z87/Art_16_Knop_1.pdf, 2019.06.14.

7. Łańcucki, J. (2003). Podstawy kompleksowego zarzadzania jakościa TQM. Poznań: Wydawnictwo Akademii Ekonomicznej.

8. Łuczak, J. (2007). Metody i techniki zarządzania jakością. Kompendium wiedzy. Poznań: Quality Progress.

9. Miller, P. (2011). Systemowe zarzadzanie jakościa. Koncepcja system, ocean system, wspomaganie decyzji. Warszawa: Difin.

10. Niezgodziński, J. (2000). Analiza wrażliwości modelu finansowego inwestycji z wykorzystaniem programu Excel. Controlling i Rachunkowość Zarzadcza, 1, pp. 15-19.

11. Szczęśniak, B. (2007). Problem automatycznego sortowania danych w arkuszu kalkulacyjnym MS Excel. Zeszyty Naukowe Politechniki Śląskiej. Seria: Organizacja i Zarzadzanie, 42, pp. 157-166.

12. Szczęśniak, B. (2010a). Arkusz kalkulacyjny w doskonaleniu procesu układania planu zajęć w szkole specjalnej. In: R. Knosala (Ed.), Komputerowo zintegrowane zarzadzanie. Vol. II (pp. 525-537). Opole: Oficyna Wydawnicza Polskiego Towarzystwa Zarządzania Produkcją. Retrieved from http://www.ptzp.org.pl/files/konferencje/kzz/artyk_pdf_2010/ 141_Szczesniak_B.pdf, 2019.06.15.

13. Szczęśniak, B. (2010b). Zastosowanie arkusza kalkulacyjnego do wspomagania metody ABC. Zeszyty Naukowe Politechniki Śląskiej. Seria: Organizacja i Zarządzanie, 50, pp. 23-33.

14. Szczęśniak, B., and Molenda, M. (2013). Spreadsheet application supporting the $x-r$ control chart. Conference Proceedings - 22th Conference Modern Mathematical Methods in Engineering (3mi), Ostrava: VSB - Technical University of Ostrava, pp. 128-134. 
15. Szczęśniak, B., and Wolniak, R. (2016). Improving the process of car operating costs accounting using a spreadsheet-based tool - a case study. 16th International Multidisciplinary Scientific GeoConference SGEM 2016, SGEM2016 Conference Proceedings, Sofia: STEF92 Technology, book 2, vol. 1, pp. 239-246. doi: 10.5593/ SGEM2016/B21/S07.031.

16. Wilczewski, S., and Wrzód, M. (2008). Excel 2007 w firmie. Controlling, finanse i nie tylko. Gliwice: Helion.

17. Winston, L.W. (2011). Microsoft Excel 2010. Data Analysis and Business Modelling. Washington: Microsoft Press.

18. Zasadzień, M., Szczęśniak, B., and Skotnicka-Zasadzień, B. (2017). Implementation of maintenance employees' work time scheduling. Proceedings of the Second International Conference on Economic and Business Management. FEBM 2017. Atlantis Press, pp. 226-231. doi:10.2991/febm-17.2017.29. 